\title{
Continuous Ambulatory Peritoneal Dialysis 患者に
}

\author{
抢ける非特異的免疫機能
}

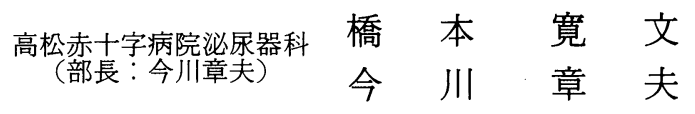

\section{NON-SPECIFIC IMMUNE RESPONSE IN PATIENTS ON CONTINUOUS AMBULATORY PERITONEAL DIALYSIS}

\author{
Hirofumi Hashimoto and Akio Imagawa \\ Department of Urology, Takamatsu red Cross Hospital, Takamatsu, Japan \\ (Director: Akio Imagawa)
}

It is known that immune response is decreased in patients during chronic hemodialysis (HD), but there have been few reports on the immune response of patients undergoing continuous ambulatory peritoneal dialysis (CAPD). We recently carried out a comparative study on the immune response of patients in CAPD and HD, employing non-specific immune parameters as indexes. The results were as follows. 1) The incidence of OKT8 positive cells was significantly lower in the CAPD group than in the HD group, and the OKT4/OKT8 ratio tended to be higher in the CAPD group. 2) The ADCC activity was closer to the normal level in the CAPD group than in the HD group. 3) In the CAPD group, a possibility of improvement in the PHA skin test soon after the initiation of CAPD was suggested. 4) The serum complement components level, especially the C3 level, was significantly higher in the CAPD group than in the HD group, and the level was found to have been normalized. These results indicate improvement in some of the immune parameters in the CAPD group in comparison with the HD group. It was thus suggested that, in the treatment of patients with chronic renal insufficiency, CAPD is a better dialysis method than HD from the aspect of preventing immunodeficiency.

\footnotetext{
要旨：慢性血液透析患者では免疫機能が低下していることは周知の事実であるが CAPD 患者での免疫 機能に関する報告は少ない.今回, 我々はCAPD 患者と HD 患者について非特異的免疫パラメーターを 指標とし免疫機能を比較検討したので報告する，1）OKT8陽性細胞百分率は CAPD 群が HD 群に比し 有意に低下し, OKT4/OKT8は CAPD 群で高い傾向にあった。2）ADCC 活性は CAPD 群が HD 群より も正常に近かった．3）PHA 皮内テストはCAPD 群では導入早期に改善する可能性が示唆された。4） 血清補体蛋白量, 特に C3は CAPD 群では有意に高く, 正常化していた。 以上の結果より CAPD 群では HD 群に比し, 免疫パラメーターの一部に改善がみられることが示され, 慢性腎不全患者の免疫不全につ いては CAPD の方が HD よりも有効な透析法である可能性が示唆された。
}

\section{緒 言}

CAPD (Continuous Ambulatory Peritoneal

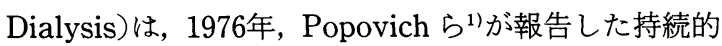
に腹膜透析を行なら方法で, 種々の改良 ${ }^{2)}$ 五がなされ て, 新しい自己管理家庭透析法として普及しつつある。

CAPD は緩徐な溶質の移動や蛋白の漏出などの腹 膜透析の特徵のうえに, 従来の IPD (Intermittent Peritoneal Dialysis) やHD (Hemodialysis) では未
解決の，持続透析が可能な一種の装着型人工腎臓とし ての機能をもっている。 そのため, 特別の設備が不要 で，医療スタッフを少なくすることができるなど，低 コストの透析療法である。しかも, 抗凝固剤が不要で あり，食事制限が少ないなどの利点を合わせもってい る.さらに, CAPD は従来の血液浄化法に比べ, 不均 衡症候群が少ない, 貧血が改善されるなど, 種々の合 併症に対して効果があることも報告されている226). 
CAPD の特徵の一つは, 従来の HD に比べ小分子量 物質の除去は劣るが, 中分子量物質や蛋白まで除去す るといら腹膜のもつ溶質の除去特性である。このこと から, 従来から血液透析患者にみられる免疫不全 ${ }^{8) ~ 25)}$ の原因であると考えられている中分子量領域以上にあ る uremic toxins の除去も期待でき，その結果として 免疫機能の改善が予想される。

著者はこの点に注目し，CAPD 患者の非特異的免疫 機能について検討を加え, 若干の知見を得たので報告 する。

\section{対象および方法}

CAPD を施行している34歳から88歳 (平均年齢54.0 歳）男性 6 例，女性 5 例を対象とした。原疾患は慢性 系球体腎炎 5 例, 糖尿病性腎症 3 例, 慢性腎孟腎炎 2 例, 痛風腎 1 例で, CAPD 導入後平均透析期間は, 5.9 カ月である。対照として, CAPD 群に, 性, 年齢, 原 疾患などが類似するよ5に HD 患者から男性 6 例, 女 性 4 例を選んだ。年齢は42歳から73歳で平均 54.0 歳, 原疾患は慢性系球体腎炎 8 例, 糖尿病性腎症 2 例, 透 析期間は平均 29 力 月 CAPD 群に比し有意に長期間 である(表 1).

これらの CAPD 群, HD 群両群について各種の非特 異的免疫パラメーターについて検討を加えた。細胞性 免废能に関しては，1）末梢血リンパ球数，2） T cell subsets, 3) ADCC (antibody dependent cell-mediated cytotoxicity) 活性, 4) PHA (phytohemagglutinin)皮内テスト, 5) PPD (purified protein derivative of tuberculin) 皮内テストを施行した. T cell subsets はモノクローナル抗体を用いたフローサイト メトリー法, ADCC 活性は, プラークアッセイ法で測

表 1 Descriptive data for respondents

\begin{tabular}{cl|c|c}
\hline & & CAPD & HD \\
\hline \multirow{2}{*}{ Sex } & Male & 6 & 6 \\
& Female & 5 & 4 \\
\hline \multirow{2}{*}{ Age } & Mean & 54 & \multicolumn{2}{c}{54} \\
& Range & $34 \sim 88$ & $42 \sim 73$ \\
\hline \multirow{2}{*}{ Causative Disease } & CGN 5 & CGN 8 \\
& & DN 3 & DN 2 \\
& CPN 2 & \multicolumn{2}{|c}{} \\
\hline
\end{tabular}

CGN : Chronic glomerulonephritis

DN : Diabetic nephropathy

CPN : Chronic pyelonephritis

GK : Gout kidney
定した。PHA 皮内テストは Wellcome 社の HA16を 生理食塩水で希採し， $0.1 \mathrm{ml}$ が $5 \mathrm{mcg}$ となるように調 整し $0.1 \mathrm{ml}$ を使用した。 PPD 皮内テストは日本ビー シージー製造株式会社の精製ツベルクリンを $0.1 \mathrm{ml}$ （PPD 0.5mcg）を使用した. PHA 皮内テスト, PPD 皮内テストの值は紅斑の直径と短径の積の根で表わし た. 液性免疫能については，1）血清補体蛋白量, 2) 血 清免疫グロブリン濃度を測定した。 また, 免疫抑制物 質として考兄られている，1）IAP (immunosuppressive acidic protein), 2) TPA (tissue polypeptide antigen)を測定した。血清補体蛋白量, 血清免疫グロ ブリン濃度, および IAP は一元放射免疫拡散法で, TPA はRIA 法で測定した。 T cell subsets抢よび $\mathrm{ADCC}$ 活性の正常群は当院職員10名より, IAP の正常 群は当院職員 35 名より求めた。

\section{結 果}

1）細胞性免疫能

末梢血リンパ球数は $\mathrm{HD}$ 群 $1,427.0 \pm 710.2 / \mathrm{mm}^{3}$, CAPD 群1,607.1 $\pm 921.7 / \mathrm{mm}^{3}$ と両群間に有意差はな かった。しかし，標準偏差が大きく，低值を示す症例 が両群とも比較的多く認められた（図 1).

$\mathrm{T}$ cell subsets は，末梢血 $\mathrm{T}$ 細胞総数とされている OKT3陽性細胞百分率が HD群で64.3土11.6\%, CAPD 群で $63.1 \pm 13.7 \%$ と両群間に有意差はなく, 両 群とも正常群より $1 \%$ 以下の危険率で有意に低下して いる. inducer および Helper T cellの比率を示す OKT4陽性細胞百分率は HD 群 $38.0 \pm 8.9 \%$, CAPD 群 $42.3 \pm 11.2 \%$ と両群間に有意差はなかった. Suppressor T cell の比率を示す OKT8陽性細胞百分率は

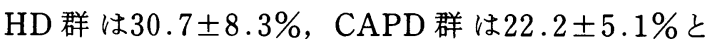
CAPD 群では HD 群に比し $1 \%$ 以下の危険率で有意

図 1 Number of lymphocytes of peripheral blood

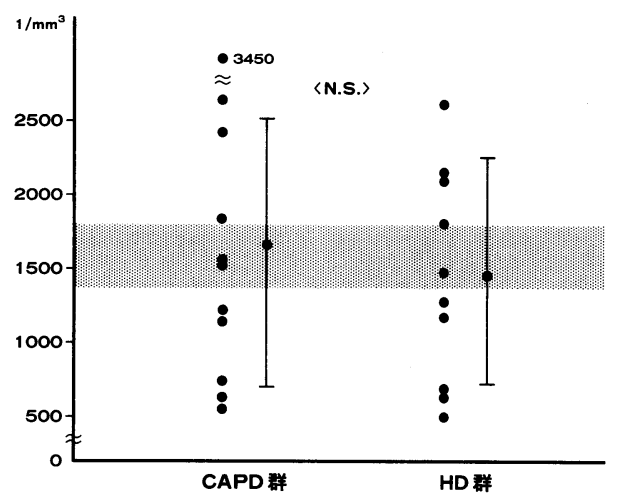


圆 2 T cell Subsets

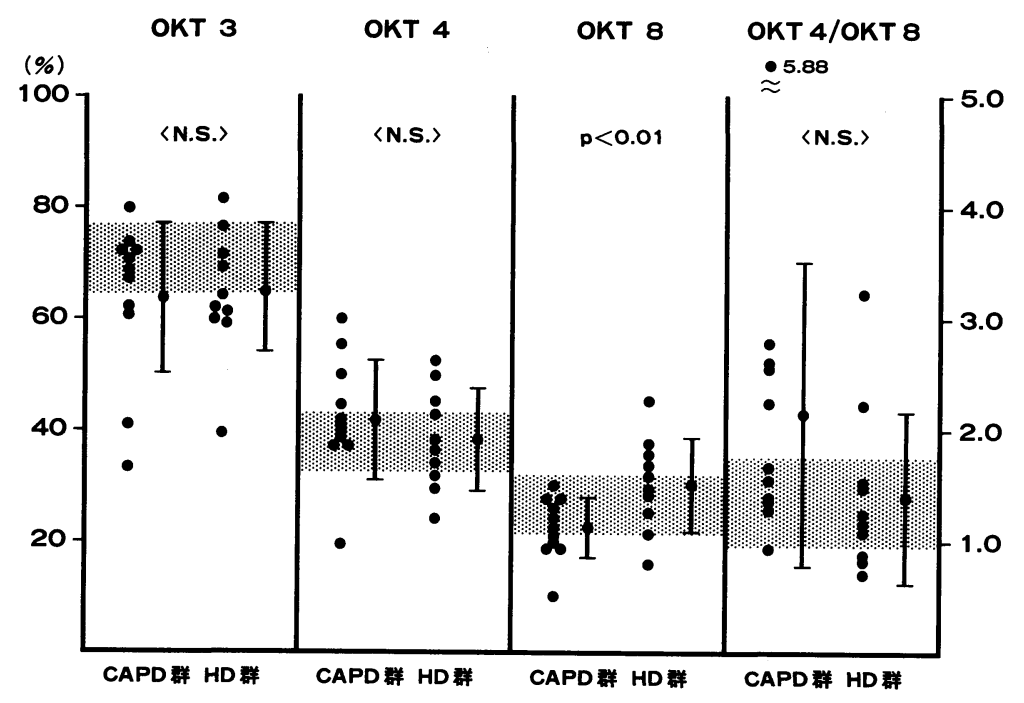

図 3 ADCC (Antibody Dependent Cell-mediated Cytotoxity)

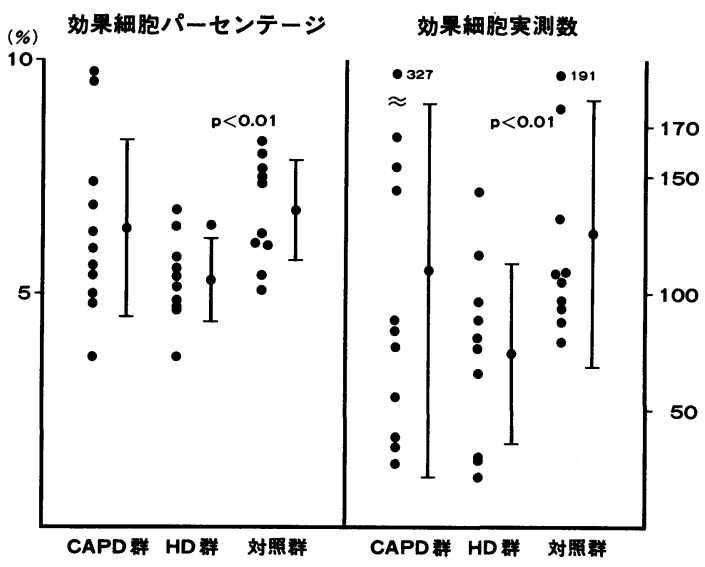

に低下している。また，免度調節機能のパラメーター といわれているOKT4/OKT8比は両群間に有意差は ないが，CAPD 群で高值の傾向にあった（図 2 ）.

$\mathrm{ADCC}$ 活性の効果細胞は百分率では, $\mathrm{HD}$ 群5.26土 $0.87 \%$, CAPD 群 $6.36 \pm 1.88 \%$, 実測数では, HD 群

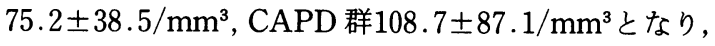
百分率, 実測数とも正常群に比し, HD 群では有意に低 下しているが, CAPD 群では正常群と有意差はなかっ た（図 3 ）。

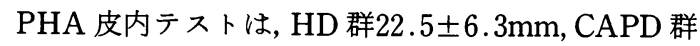
$27.1 \pm 16.7 \mathrm{~mm}$ と両群間に有意差はないが，HD 群が 全例低值を示すのに比べ, CAPD 群では正常値を示す
図 4 Values of PHA and PPD skin test PHA skin test PPD skin test

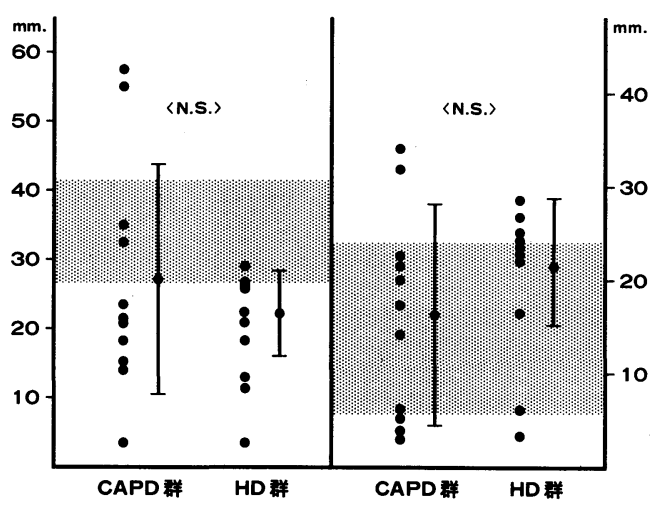

症例, hyperimmune と考光られる高值を示す症例が 散見された. PPD 皮内テストは, HD 群 $22.4 \pm 6.8 \mathrm{~mm}$, CAPD 群 $16.7 \pm 12.1 \mathrm{~mm}$ と両群間に有意差はなかっ た（図 4 ）.

\section{2）液性免疫能}

血清免疫グロブリン濃度は, IgM が HD群で $127.6 \pm 45.1 \mathrm{mg} / \mathrm{dl}, \mathrm{CAPD}$ 群 で102.2 $\pm 55.0 \mathrm{mg} / \mathrm{dl}$, IgG が HD 群 で $1,570.0 \pm 448.6 \mathrm{mg} / \mathrm{dl}$, CAPD 群で

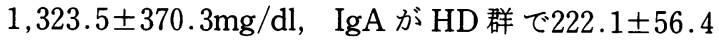

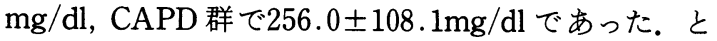
もに各群間に有意差はないが, CAPD 群では IgM, IgG 濃度が低い傾向にあった（図 5 ）.

血清補体蛋白量は, C3が HD 群で51.3 $10.4 \mathrm{mg} / \mathrm{dl}$, 
図 5 Levels of serum immunoglobulin

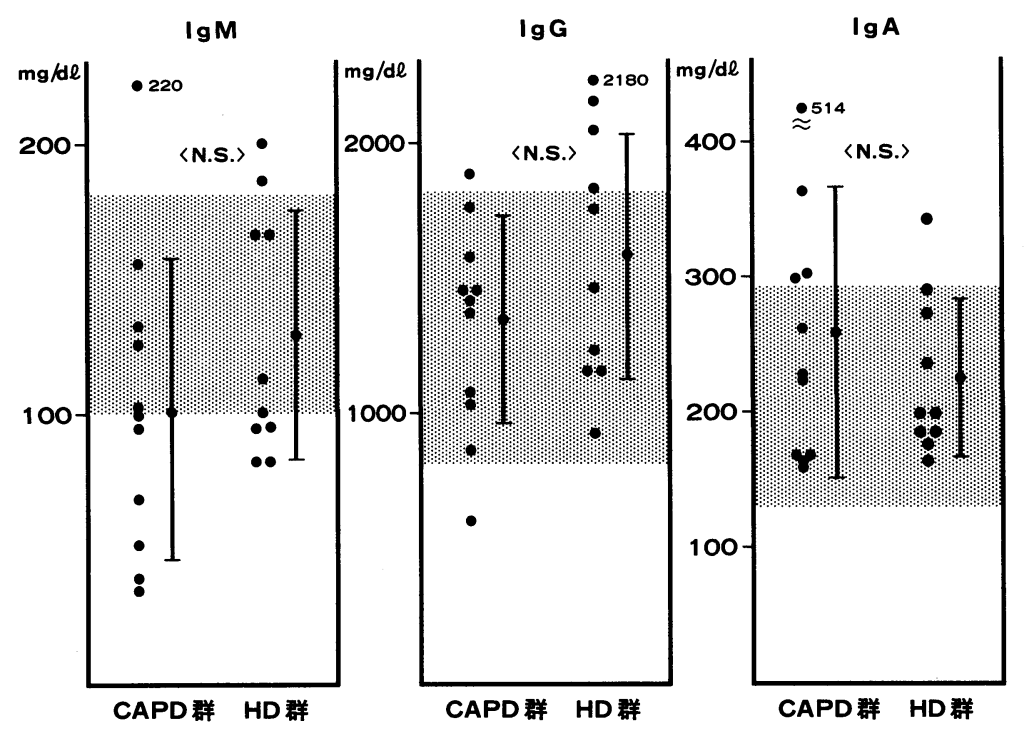

図 6 Levels of Complement Proteins c 3

$$
\text { C } 4
$$

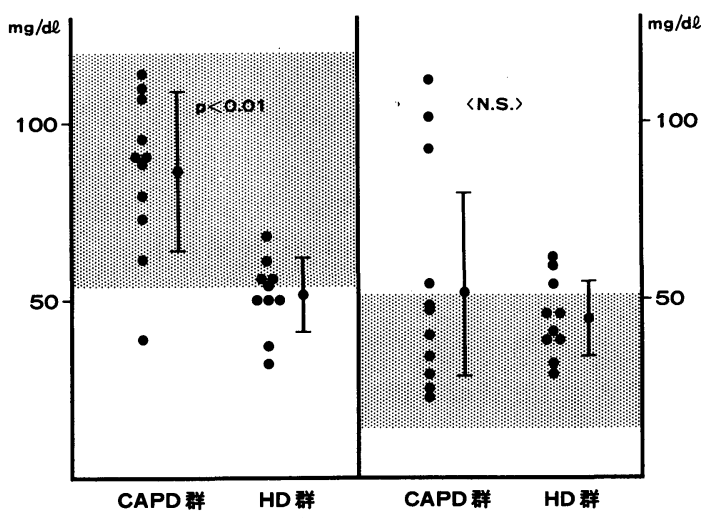

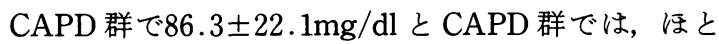
んぞの症例が正常域にあり, CAPD 群が $1 \%$ 以下の危 険率で HD 群よりも有意に高かった。C4はHD群で $43.4 \pm 10.2 \mathrm{mg} / \mathrm{dl}, \mathrm{CAPD}$ 群で $51.8 \pm 28.1 \mathrm{mg} / \mathrm{dl}$ と両 群間に有意差はないが CAPD 群でやや高い傾向にあ る(図 6 ).

\section{3）免疫抑制蛋白}

IAP は HD 群 $706.0 \pm 191.6 \mu \mathrm{g} / \mathrm{ml}, \mathrm{CAPD}$ 群 $623.3 \pm 130.1 \mu \mathrm{g} / \mathrm{ml}$ と両群間に有意差はなく, ともに 正常群 $(446.6 \pm 159.1 \mu \mathrm{g} / \mathrm{ml})$ に比し高值を示した. TPA は HD 群で $151.0 \pm 26.9 \mathrm{U} / \mathrm{L}, \mathrm{CAPD}$ 群で
図 7 Levels of serum IAP and TPA
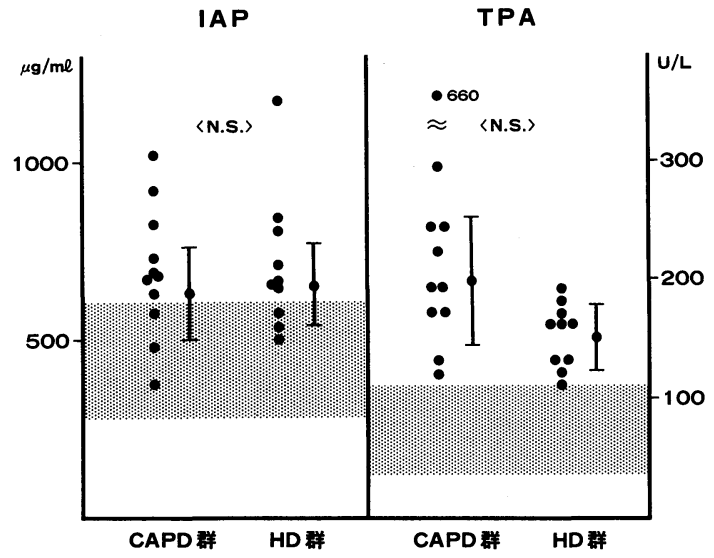

$238.2 \pm 148.5 \mathrm{U} / \mathrm{L}$ と両群間に有意差はなく，正常域 (38〜110U/L)より高值を示した（図 7 ). しかし, IAP, TPA ともに他のパラメーターとの間に相関関係は認 められなかった。

\section{考察}

腹膜は生体のもつ優れた透析膜で，タンパク透過膜 であることより 1 日 $6 \sim 9 \mathrm{~g}$ のンパク喪失がある が6), その反面, 腎不全患者の免疫不全に関与すると想 定されている中分子量以上の液性因子が除去される可 能性があり, 免疫機能の改善が期待される. IPD では 血液透析に比し免疫能が改善するという報告 ${ }^{25)} ゙$ ある 
が, CAPD 患者に関しては HD 患者よりも血清殺菌力 の低下が少なく ${ }^{41)}$, in vitro での PHA 刺激によるリン 球幼若化能が HD 患者よりも良化している ${ }^{42)}$, HD からCAPDに移行した患者でリンパ球幼若化能は低 下したままであった ${ }^{42)}$ な゙の報告があるにすぎない。 そこで, 今回, CAPD 患者の免度機能について若干の 検討を加えた。

腎不全もしくは透析患者では末梢血リンパ球数は減 少しているとの報告は多い. Touraine ら 20 は血液透析 患者群と対照群で血液中の単核細胞の比率を比較検討 し, 大リンパ球, 単球, 組織球には有意差を認めない が血液透析患者では小リンパ球が有意に低下している と報告し，著者ら ${ }^{199}$ も透析患者の末梢血リンパ球数は

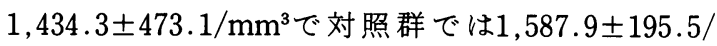
$\mathrm{mm}^{3}$ と $1 \%$ \%の危険率で有意に低下していること を報告した。 また，尿毒症患者の血清中には正常リン パ球刺激を阻害する中分子量以上の液性因子が存在す ることが想定され，骨䯣前駆細胞の分化や成長を阻止 することが多くの報告により立証されている20127)28).

今回の検討では, CAPD 患者群でも末梢血リンパ球 数は, 対照群より低值を示す症例が多く, CAPD 導入 後の透析期間が短いことが関与している可能性があり 今後の検討が待たれる.

また，腎不全患者の免疫抑制と関係のある Tリンパ 球数についての報告 ${ }^{19) ~ 21) ~}$ も多く, そのほとんどがTり ンパ球数は低下していると報告されている。我々は今 回, リンパ球表面抗原に対するモノクローナル抗体を 使用し，機能を異にする Tリンパ球サブセットについ て検討した。まず，Tリンパ球総数とされる OKT3陽 性細胞は HD 群とCAPD 群には有意差はなく, 両群 とも対照群より有意に低下していた。また, inducer お よび Helper T 細胞の比率を示す OKT4陽性細胞百分 率も両群間には有意差はなかったが, Suppressor T 細 胞の比率を示す OKT8陽性細胞百分率は CAPD 群で は HD 群に比し $1 \%$ 以下の危険率で有意に低下して いた。ささらに，免度調節機能のパラメーターといわれ るOKT4/OKT8比は, 両群間に有意差はないが, CAPD 群で高值の傾向にあった。つまり, CAPD 群で は抗体産生を抑制する Suppressor T 細胞が少なく, 免疫抑制状態は HD 群より強くないことが示唆され る.

ついで, $\mathrm{K}$ 細胞機能を反映するとされている ADCC 活性 ${ }^{29)}$ は HD 群では対照群に比し, 効果細胞百分率, 実測数とも有意に低下していたが, CAPD 群では対照
群と有意差はなかった. $\mathrm{ADCC}$ 活性の効果細胞として 単球やマクロファージも同定されることから ADCC 活性は $\mathrm{K}$ 細胞のみの機能を反映しているとは限らな い. 伊藤 ${ }^{30}$ は血液透析患者に扣いて単球が多く含まれ ているとADCC 活性は低下しないが，それを取り除き リンパ球のみにすれば低下する。つまり, 単球の $\mathrm{ADCC}$ 活性は落ちていないが，K細胞の ADCC 活性 は落ちているとしている。 その他にも ADCC 活性に関 する報告 ${ }^{31) 331}$ はみられるが, 血液透析患者での $\mathrm{ADCC}$ 活性は低下もしくは不変であるとの見解が多 いようである.しかし，今回は HD 群とCAPD 群を同 じように処理した上での有意差であることょり， CAPD 群では抗体存在下での標的細胞に対する細胞 障害作用は正常に近いと考えられた。

さて, 腎不全患者の細胞性免疫機能を知るうえで可 及的簡便な検査法として, 著者らはPHA 皮内テスト を推奖している ${ }^{16)}$. 皮内テストは手技も簡単で採血も 不要で非侵襲的である.PHA 皮内テストは in vitroに おける PHA リンパ球幼若化率と有意の相関を示し, 紅斑部の組織学的所見は遅延型皮膚反応之同様の所見 である. PPDや Candida antigenなどによる皮内テス トは患者が感作されているかどうかが問題となり，ま た, DNCB 皮内テストは前感作を必要とし, 潰瘍形成 などの副作用がある。これに対し, PHA 皮内テストは 前感作を必要とせず, 安価で, 繰り返し行なえるとい ら利点がある。著者らは, 血液透析患者の PHA 皮内テ ストの平均値は $16.47 \pm 9.07 \mathrm{~mm}$ で対照群 $34.60 \pm 7.04$ $\mathrm{mm}$ と比し血液透析患者では有意に低下しているが, 透析患者では透析導入時は低下を示し, 透析導入が順 調で全身状態の良い症例では, 導入 3 力月目頃より上 昇しだし，1年を経過する頃より正常值で安定するこ とが多いことを以前に報告した ${ }^{16}$. 腎不全患者の血清 中にはPHA によるリンパ球の幼若化を低下させる物 質が存在し, いわゆる uremic toxins との関係が想定 されているが, PHA 皮内テストの正常化をもって細 胞性免疫に関与寸る液性因子が十分透析されたかどう かを判定することができる可能性もある，今回の検討 では, HD 群と CAPD 群で PHA 皮内テストに有意差 はなかったが, HD 群が全例低值を示すのに比べ, CAPD 群では導入後 6 カ月ですでに正常値を示す症 例が数例認められることより, 透析導入期の免疫不全 はCAPDに打いては早期に改善される可能性が示唆 された。すた，以前に透析開始後 2 年を経過しても PHA 皮内テスト值が改善しない症例に HF 
(hemofiltration)を行なったところ, $\mathrm{HF}$ 開始約 1 力月 でPHA 皮内テスト值が著明に改善した症例を経験し た ${ }^{34)}$. おそらくは, HFにより中分子量物質が除去され たための効果であろうと思われ，CAPDでも同様の機 序で免疫機能が改善される可能性があると思われる。

また，PPD 皮内テストについても検討したが，HD 群とCAPD 群の間に有意差は認められなかった. 今後 HD 導入期に多い，抗結核剤により改善する原因不明 の発熱, 結核の再発再然が CAPD 患者で少なくなるか どらか臨床的検討が必要である.

ついで，液性免疫能について血清免疫グロブリン濃 度および血清補体蛋白量を測定した。血清免疫グロブ リン濃度は, IgM, IgG, IgA とも HD 群と CAPD 群の 間に有意差はなかったが, CAPD 群では, IgM, IgGが 低值を示す傾向にあり，これは他の報告35) と同様で あったが, IgA は高值の傾向があった. CAPD 患者で は透析液中へのアルブミン亦失と同様のメカニズムで グロブリン亦失が起こると推察はされているが, 血清 IgAのデータよりは結論を出し得ない。また，長期血 液透析患者では, 血清 IgA が低下しているとの報告36) があり, HD 群における血清 $\operatorname{IgA}$ の低值は透析期間と 関係がある可能性もある。 しかし，血清免疫グロブリ ン濃度は, 両群で三者とも正常域にあり, HD 群, CAPD 群とも液性免疫能はほぼ正常と考兄られる。

補体蛋白量では, C3が CAPD 群において HD 群に 比し $1 \%$ 以下の危険率で有意に高値を示し，C4は両群 間に有意差はないが，CAPD 群で高値の傾向にあっ た.この結果はChan らの報告 ${ }^{35)}$ と同様である. 血液透 析患者では, 血液が透析膜に接触する際, alternative pathwayを介して補体系が活性化され消費されるこ とが知られておりり ${ }^{37)}$ ，このための補体蛋白量の低下が 想定される。したがって, CAPD 群では補体系感染防 御能は HD 群よりも優位である可能性が示唆された。

担癌患者で高値を示すいわゆる腫瘍マーカーの中で IAP，TPA は免疫抑制活性をもつことが知られてい $3^{38) 40}$ が，クリアランスの低下から慢性腎不全患者で も高值を示す可能性がある. IAP については血液透析 患者で測定し, 進行癌患者と同様に高值を示すことを 報告した ${ }^{39)}$. TPA については慢性腎不全患者で測定し た報告はないが，その生物学的機能として in vitroで PHA によるリンパ球の幼若化を阻止するとされてい る40)，したがって，慢性腎不全でも IAP，TPA は，免 疫抑制物質としての可能性があり検討を加えた。今回 の測定では HD 群, CAPD 群のいずれも IAP, TPA と
もに高値を示したが，他のパラメーターとの間に相関 関係は得られず慢性腎不全患者の免疫抑制の主要な役 割は乏しいと考えられた。

以上のごとく, CAPD 患者では透析導入早期である にもかかわらず, HD 群に比べいくつかの免疫パラ メーターの改善がみられている。 今後, 長期間の検討 を続けると同時に, 統計学的に癌や感染症の発生率が $\mathrm{HD}$ 患者に比べて低下するかどうかの検討も必要であ る.

\section{結 語}

CAPD 患者と HD 患者について非特異的免疫パラ メーターを指標とし，免疫機能を比較検討し，以下の 結果を得た。

1） OKT 抗体を使用したTリンパ球サブセットの らち OKT8陽性細胞百分率は CAPD 群で HD 群より 有意に低下し，OKT4/OKT8は CAPD 群で高い傾向 にあった。つまり，CAPD 群では抗体産生を抑制する Suppressor $\mathrm{T}$ 細胞が少なく, 免度抑制状態は HD 群 より強くないことが示唆された。

2) ADCC 活性から CAPD 群ではHD群より抗体 存在下での標的細胞に対する細胞障害作用は正常に近 いことがわかった。

3）PHA 皮内テストは両群間に有意差はないが, CAPD 群では導入早期に改善されることが観察され た.

4）血清補体蛋白量, 特に C3は CAPD 群で有意に高 く, 正常化していた.

5）他の各種パラメーターでは両群間に有意差は認 められなかった。

以上の結果より, CAPD 群では HD 群に比し, 免疫 パラメーターの一部に改善がみられることにより, 慢 性腎不全患者の免疫不全についてはCAPDの方が HD ๖りも有効な透析法である可能性が示唆された。

稿を終えるにあたり, 症例提供をしていただきました愛 媛県立中央病院泌尿器科部長中島幹夫先生, 川島病院川島 周先生に深謝いたします。なお, 本論文の要旨は第72回日本 泌尿器科学会総会ミニシンポジゥム一最適な血液浄化法 一に打いて発表した。

\section{文献}

1) Popovich, R.P., Moncrief, J.W., Decherd, J.F., Bomer, J.B. and Pyle, W.K.: The definition of a novel portable/wearable equilibrium peritoneal dialysis technique. Am. Soc. Artif. Intern. Organs, Abstract, 5, 64, 1976.

2）今川章夫, 山下利幸, 玉置俊晃, 橋本寛文, 川西泰 
夫 : CAPD (Continuous Ambulatory Peritoneal Dialysis)による腎不全の治療. 西日泌尿, 46, 369 $-372,1984$.

3) Oreopoulos, D.G., Clayton, S., Dombros, N., Zellerman, G. and Katyirtzaglou, A.: Experience with continuous ambulatory peritoneal dialysis. Trans. Am. Soc. Aetif. Intern. Organs, 25, 95-99, 1979.

4) Oreopoulos, D.G., Robson, M., Faller, B., Ogilivie, R., Rapoport, A. and Deveber, G.A.: Continous ambulatory peritoneal dialysis: A new era in the treatment of chronic renal failure,. Clin. Nephrol., 11, 125-128, 1979.

5) Stanley, S.A., Daniel, C.C., Ann-Frances, A., Peul, R., mercedes, A., Joseph, D., Heather, L., Susan, D.S. and Douglas, R.W. : Initial experience with continous peritoneal dialysis. Artif. organs, 3, 206-209, 1979.

6) Popovich, R.P., Moncrief, J.W., Nolph, K.D., Ghods, A.J., Twardowski, Z.J. and Pyle, W.K. : Continous ambulatory peritoneal dialysis. Ann. Intern, Med., 88, 449-456, 1978.

7) Madden, M.A., Zimmerman, S.W. and Simposon, D.P.: Longitudinal comparison of intermittent versus continous ambulatory peritoneal dialysis, kn the samp patients. Clin. Nephrol., 16, 293-299, 1981.

8) Miach, P.J., Dawborn, J.K. and Zipell, J.: Neoplasia in patients with chronic renal failure on long-term dialysis,. Clin. nephrol., 5, 101 $-104,1976$.

9）橋本寛文, 山本 明, 川西泰夫, 湯浅 誠, 今川章 夫, 寺尾尚民, 竹中 章: 血液透析患者の尿路感染 症. 透析会誌，18，469-472，1985.

10）橋本寛文, 山本 明, 川西泰夫, 湯浅 誠, 今川章 夫, 三好康夫：糖尿病性腎症に上る血液透析患者 の尿路感染症．透析会誌，18，619-623，1985.

11) Lazarus, J.M.: Complications in hemodialysis: An overview. Kidney Int., 18, 783-796, 1980.

12) Keane, W.F., Shapiro, F.L. and Raij, L.: Incidence and type of infections occuring in 445 chronic hemodialysis patients. Trans., AM. Soc. Artif. Intern. organs, 23, 41-46, 1977.

13) Dobkin, J.F., Miller, M.H. and Steibigel, N.H. : Septicemia in patients on chronic hemodialysis. Ann. Intern. med., 88, 28-33, 1978.

14) Nsouli, K.A., Lazarus, J.M., Schoenbaum, S.C., Gottlieb, M.N., Lowrie, E.G. and Shocair, M. : Bacteremic infection in hemodialysis. Archs. Intern, med., 139, 1255-1258, 1979.

15) Mintogomerie, J.Z,, Jalmanson, G.M. and Guze,
L.B.: Renal failure and infection. Medicine. Baltimore, 47, 1-32, 1968.

16）今川章夫, 海部泰夫, 辻村玄弘：透析患者の感染防 御能. 第 2 報, Phytohemagglutinin 皮内テスト. 西日泌尿, 40，483-486， 1978.

17）今川章夫, 前林浩次, 湯浅 誠, 滰川 浩：透析患 者の感染防御能. 第 4 報。風疹. 西日泌尿, 40,661 $-663,1978$.

18）今川章夫, 滝川 浩, 中島幹夫：透析患者の感染防 御能．第 5 報。結核症．西日泌尿，40，665-667, 1978.

19）今川章夫, 太田輝和：透析患者の感染防御能. 第 6 報. 末梢血リンパ球数. 西日泌尿, 41, 1029-1032, 1979.

20) Touraine, J.L., Touraine, F., Revillard, J.P., Brochier, J. an Traeger, J.: T Lymphocytes and serum inhibitors of cell-mediated immunity in renal insufficiency. Nephron, 14, 195-208, 1975.

21) Wendy, E.H., Rafael, V.M. and Richard, B.F.: Deficiency of $T$ and $B$ lymphocytes in uremic subjects and partial improvement with maintenance hemodialysis. Nephron, 20, 182-188, 1978.

22) Dobbelstein, H.: Immune system in uremia. Nephron, 17, 409-414, 1976.

23) Traeger, J., Touraine, J.L., navarro, J., Freyia, J. an Contreras, P.: Immunodeficiency in chronic renal insufficiency, Proc. E.D.T.A., 17, 375-382, 1980 .

24) Boulton-Jones, J.M., Vick, R., Cameron, J.S. and Blacj, P.J.: Immune response in uremia. Clin. Nephro., 1, 351-360, 1973.

25) Nemeth, L., Gofman, L., Karatson, A. and Hamori, A. : Effect of haemo- and peritoneal dialysis on the cell-mediated immune response in chronic uraemia. Inter. Uro. and Nephr., 12, 375-384, 1980.

26) Oreopoulos, D.J., Khanna, R., Williams, p. and Vas, S.I.: Conitunous ambulatory peritoneal dialysis-1981. Nephron, 30, 293-303, 1982.

27) Jensson, O.: Observations on the leucocyte blood picture in acute uremia. Brit,. J. Haemat., 4, 442-427, 1958.

28) Riis, P. and Stougaard, J.: The peripheral blood leucocytes in chronic renal insufficiency. Pan. Med. Bull, 6, 85-90, 1959.

29）仙道富士郎：Antibody dependent cell-mediated cytotoxicity (ADCC). 臨床検査 Mook, 3, 155 $-162,1980$.

30）伊藤恭吾, 花梅 清, 熊谷勝男：尿毒症に抢ける免 疫不全. 臨床免疫，12，607-614，1980。 
31）松尾清一, 内藤耕太郎, 加藤正達, 浅井幹一, 両角 国男, 晋天間新正, 伊藤 晃, 大倉誉揚, 坂本伸夫, 山崎規雄, 川原弘久: 血液透析患者リンパ球の細 胞障害作用について一(第一報). 透析会誌, 11, 455 $-456,1978$.

32）高橋 寿, 安部 徹, 太宰幸子, 高橋一江, 石崎 充, 門間弘道, 関野 宏, 金田 嚴, 里見 進, 熊 谷勝男：生体腎移植患者および慢性腎不全患者の antibody dependent cell-mediated cytotoxicity. 医学のあゆみ, 107, 387-390, 1978.

33) Badger, A.M., Bernard, D.B., Idelson, B.A. and Cooperband, S.R. : Depressed spontaneous cellular cytotoxicity associated with normal or enhanced antibody dependent cellular cytotoxicity in patients on chronic hemodialysis. Clin. Exp. Immunol., 45, 568-573, 1981.

34）今川章夫, 滝川 浩, 玉置俊晃, 米沢正隆：透析患 者の感染防御能. 第 7 報. Hemofiltrationにより 免疫パラメーターの改善した 1 例. 西日泌尿, 41, 1033-1035, 1979.

35) Chan, M.K., Bailod, R.A., Varghese, Z, Sweeny, P. an Moorhead, J.F.: Immunogloburins and complement components $(\mathrm{C} 3, \mathrm{C} 4)$ in $\mathrm{CAPD}$ and hemodialysis patients. Dialysis \& Transplantation, 12, 777-778, 1983.

36）佐藤英一：血液透析患者の感染と特徵. 透析会誌, 6, 142-144, 1973 .

37）今川章夫, 海部泰夫, 中島幹夫 : 透析患者の感染防
御能. 第 1 報. 血清免疫グロブリンおよび補体蛋白 量. 西日泌尿, 40,341-345, 1978.

38）石田名香雄，田村啓二, 柴田芳実：免疫抑制酸性蛋 白の性状と癌患者における検出意義。医学のあゆ み, 115, 423-433, 1980.

39）玉置俊晃：IAP の問題点一腎不全患者の IAP 値 について一。西日泌尿, 45，306-307， 1983.

40) Bjorkiund, B. an Bjorkund, V.: Antigenicity of pooled human malignant and normal tissues by cytoimmunological technique: Presence of an insoluble, heat-labile tumor antigen. Int. Arch. Allergy, 10, 153-184, 1957.

41) Bertazzoni, E.M. and Panzetta, G. : Effects of different forms of dialytic treatment on serum antibacterial activity patients with chronic renal failure. Nephron, 36, 224-229, 1984.

42）森川洋二：慢性腎不全患者の免疫能に関する研 究. 第 3 報. Continuous ambulatory peritoneal dialysis 治療患者の免疫能について. 透析会誌, 16, 225-229, 1983.

43) Singh, S., Hurtubise, P., Michael, G., Pesce, ;A. and Pollak, V.: Preliminary observations on the laboratory markers of cell-mediated immunity in patients transferring from hemodialysis to continuons peritoneal dialysis. Contr. Nephrol., 36, 73-81, 1983.

（1986年 5 月 15 日受付） 